\title{
CARTOGRAFIA DOS TERRITÓRIOS DA ESCOLA: MAPEANDO ESPAÇOS HETEROTÓPICOS DE LAZER QUE POSSIBILITAM INFLEXÕES DE APRENDIZAGEM
}

Recebido em: $31 / 03 / 2020$

Aprovado em: 05/12/2020

Licença:@) (1) @

Leandro Veloso Silva ${ }^{1}$

Faculdade Presbiteriana Gammon (FAGAMMON)

Lavras - MG - Brasil

RESUMO: Este artigo apresenta passos e reconhecimentos de uma pesquisa de doutorado, que buscou abordar e problematizar questões no entorno do sujeito social 'criança' no seu processo de conhecer e aprender no decorrer do 'brincar' nos momentos de 'lazer' da/na 'infância' nos territórios da Escola. Para tanto, se subsidia num movimento de uma pesquisa bibliográfica, ancorada nos caminhos metodológicos desenhados por meio de uma pesquisa qualitativa e pós-crítica, tendo como rota a abordagem de uma cartografia. Nesse sentido, teve como objetivo se movimentar com a escola e com seus atores e sujeitos sociais, para 'compreender como a cartografia pode mapear espaços dentro dos territórios da escola, e, desta forma, apontar os acontecimentos de inflexões de aprendizagem, por meio das práticas sociais presentes nos brincares dessas crianças em lugares identificados e denominados como sendo 'espaços heterotópicos de lazer'.

PALAVRAS-CHAVE: Lazer-Educação. Espaços Heterotópicos. Escola.

\section{CARTOGRAPHY OF SCHOOL TERRITORIES: MAPPING HETEROTOPIC SPACES OF LEISURE THAT ENABLE LEARNING INFLECTIONS}

ABSTRACT: This article presents steps and acknowledgments of a doctoral research, which sought to address and problematize issues surrounding the social subject 'child' in their process of knowing and learning in the course of 'playing' in the 'leisure' moments of / in 'childhood 'in the School's territories. To this end, it is subsidized in a movement of a bibliographic research, anchored in the methodological paths designed through a qualitative and post-critical research, having as a route the approach of cartography. In this sense, it aimed to move with the school and with its actors and social subjects, in order to 'understand how cartography can map spaces within the school's territories, and, in this way, point out the events of learning inflections, through the social practices present in the play of these children in places identified and called as 'heterotopic leisure spaces'.

\footnotetext{
${ }^{1}$ Professor Doutor em Estudos do Lazer - Área de concentração: Cultura e Educação - EEFFTO/UFMG; Mestre em Educação - UFLA; Especialista em Educação - UFLA; Especialista em Esporte Escolar - UnB; Graduado em Educação Física Lic/Bach - FAGAMMON. Professor da Rede Municipal de Ensino de Lavras MG e da Faculdade Presbiteriana Gammon.
} 
KEYWORDS: Leisure-Education. Heterotopic Spaces. School.

\section{Desenhando os Primeiros Traços dos Territórios...}

$\mathrm{Na}$ produção destes estudos, o movimento de pesquisa apresenta uma proposta de reconhecimentos que se insere no campo das Ciências Sociais, Humanas e nos Estudos do Lazer, pela proposição de abordar e problematizar questões no entorno do sujeito social 'criança' no seu processo de conhecer e aprender no decorrer do 'brincar' da/na 'infância', verificados em espaços que podem ser considerados como de lazer e que no movimento de pesquisa busca-se identificar e mapear no relevo e geografia da escola.

Propõe problematizar não tão somente o movimento do corpo da criança que aprende brincando, mas também mapear os espaços que essa criança percebe, descobre e se apropria na escola, e que na interação dos brincares passa a aprender e a reconhecer de muitas formas diferentes o mundo ao seu redor.

Pois a compreensão de aprendizagem percebida nos brincares das/nas infâncias, possibilitada pelas relações humanas e pelas práticas sociais que se estabelecem, produz territorialidade e cultura.

Tais interfaces que permeiam a educação do sujeito social 'criança', nessas verificações, podem subsidiar-se pelos contributos dos Estudos Culturais articulados aos contributos dos Estudos do Lazer, que na intenção de desenhar uma pesquisa póscritica, vislumbra identificar processualidades educacionais em acontecimentos das e nas infâncias, localizados intencionalmente em espaços de lazer aqui identificados nos territórios ${ }^{2}$ da escola.

\footnotetext{
${ }^{2}$ Compreende-se aqui, a partir de reflexões das 'ciências geográficas' que ‘territórios' são delimitações do espaço geográfico cujo âmbito visual pode ser definido como paisagem. No movimento desse estudo, entenderemos território como sendo um local, um lugar e um espaço concreto que em um tempo
} 
Não há, com a produção destes estudos, qualquer intenção de contemplar discussões, reforçar ou defender, posicionamentos teóricos sobre qualquer tentativa ou modelo de escolarização da infância para o cenário da educação da criança na escola, ou de apenas tentar atestar os espaços e territórios da escola como equipamentos de lazer.

O que se pretende é instaurar possibilidades outras para os territórios da escola, oportunizando problematizações quanto à utilização de seus espaços localizáveis e identificáveis para 'os brincares' da e na infância, para 'o lazer' da e na infância que aprende e adquiri novos saberes.

Para tanto, o direcionamento de nossos olhares foram traçados a partir de uma ótica que contempla a percepção de crianças em seus espaços de educação, compreendendo uma faixa etária que variou dos 5 aos 7 anos, sendo/estando ela pertencente à última etapa da Educação Infantil ou Primeira Série do Ensino Fundamental da Educação Básica ${ }^{3}$, o que reforça que nossa intencionalidade foi/é percebê-la enquanto e como criança que compõe a geografia e paisagem de uma ‘instituição educacional' e que, portanto, desenha o ‘território escolar'.

Nesse sentido, o foco e interesse pensado para essa produção advêm da minha trajetória de formação e atuação como professor de Educação Física, que vivência, experimenta, e descobre sempre novas possibilidades de ensinar e aprender nestes territórios.

Por isso o foco em refletir e produzir conhecimento acerca dos processos de ensino e aprendizagem da infância e suas práticas corporais e sociais na/da escola, surge

determinado adquiri limites estabelecidos socioculturalmente, pois a produção de espaços sociais é em sua essência, um processo de territorialidade. Territorialidade que se estabelece na dinâmica social, como produto das relações sociais de 'espaço-poder' manifestadas nas ações dos sujeitos sociais. "O território envolve sempre, ao mesmo tempo, mas em diferentes graus de correspondência e intensidade, uma dimensão simbólico-cultural, através de uma identidade territorial atribuída pelos grupos sociais como forma de 'controle simbólico' sobre o espaço onde vivem (sendo, portanto, uma forma de apropriação) e uma dimensão mais concreta, de caráter político disciplinar: o domínio do espaço pela definição de limites ou fronteiras visando a disciplinarização dos indivíduos e o uso/controle dos recursos aí presentes" (HAESBAERT, 1997, p.42).

${ }^{3}$ Participam destes estudos e compõem nossos 'territórios escolares', instituições educacionais/escolas da Rede Pública Municipal e da Rede Privada de ensino na Cidade de Lavras - Sul de Minas Gerais (Para saber mais sobre o município e suas instituições de ensino acesse: http://pml.lavras.mg.gov.br/). 
pela percepção de que esse é o espaço onde o lazer e o brincar, representam momentos em que o sujeito social - criança - se constrói, desconstrói, reconstrói pelo contato com o grupo social (SILVA; RIBEIRO, 2018).

Momentos que podem representar 'inflexões de aprendizagem' das infâncias, pois estas inflexões se traduzem num 'movimento interno de mudança', a partir de reconhecimento e transformação de saberes, de posturas e principalmente da forma como aprender e educar-se na interação e experimentação dos acontecimentos (SILVA, 2013).

Ponto de inflexão e/ou inflexão equivale a um movimento interior que permite acontecer e se perceber mudanças. É um conceito matemático utilizado [deslocado] para designar que em algum momento aconteceram movimentos e mudanças e que algo se modificou e se transformou na estrutura do pensamento, do comportamento e do conhecimento que se tem (SILVA, 2013, p. 32).

Inflexões estas que podem redimensionar a percepção e interpretação de acontecimentos dos saberes, aprendizagens e práticas sociais, e nos inundar de curiosidades e questionamentos, tais como: É possível mapear espaços de lazer nos territórios da escola?! É possível relacionar aprendizagem com acontecimentos nos brincares e lazer das infâncias na escola?!

Diante de tais questões o que se buscou foi instaurar 'espaços' para formas de compreensão ainda mais ampla de 'lazer', de 'educação', da 'criança que brinca na infância' e se educa no seu tempo livre, e em seu tempo e espaço de satisfação e prazer, para assim redimensionar a aprendizagem em estudos que poderão também dimensionar a visão do lazer, de educação, dos espaços e territórios da escola, da criança que brinca e aprende por meio do que podemos entender como "lazer-educação" (DATTILO, 2015).

John Dattilo (2015), perspectivando o 'lazer-educação', propõe lançar olhares para construção e estabelecimento de modelos de trabalhos educativos em espaços que 
envolvam e percorram situações de lazer e de educação que se sustentam e ganham significado mais amplo por propor atividades, vivências e experiências capazes de estimular e equilibrar a participação social.

Participação motivada pela capacidade de interagir, se posicionar, ser e se tornar parte do grupo social, através de momentos sistematizados para esses acontecimentos resultantes em aprendizagens (DATTILO, 2015).

Aprendizagens estas, que nos territórios da escola podemos dizer que acontece de forma coletiva e situada nos mais diversos espaços destinados aos brincares e simultaneamente ao lazer das infâncias e do mundo que cerca cada criança.

Nesse sentido, o objetivo da pesquisa é se movimentar com a escola e com seus atores e sujeitos sociais para 'compreender como a cartografia pode mapear espaços dentro dos territórios da escola, e, desta forma, apontar os acontecimentos de inflexões de aprendizagem, por meio das práticas sociais presentes nos brincares dessas crianças em lugares que identificamos e denominamos como sendo 'espaços heterotópicos de lazer'.

Pois é fato que escola se constitui em uma rota identificável e construída pela sociedade para a formação e aprendizagem de seus sujeitos sociais e do próprio grupo social em que esses sujeitos se inserem.

Essa potencialidade da escola é inegável, tanto mais que a maioria das crianças crescem e aprendem em seus espaços, por meio do brincar, do seu momento de lazer e tempo livre ${ }^{4}$ e, ainda, por meio das práticas sociais que se estabelecem nesses momentos e acontecimentos, pois o tempo livre, o tempo de brincar, o tempo de lazer também

\footnotetext{
${ }^{4}$ Entendemos 'tempo livre', conforme nos sugestiona a compreender Lopes (2004), como tempo fora das obrigações pessoais, que sobra depois de ter satisfeito todas as necessidades, tempo associado, portanto ao descanso, ao estado de ócio, de repouso, de liberdade, para o sujeito social criar e/ou fazer o que quiser; fazer qualquer coisa, brincar, descansar.
} 
devem ser considerados tempo de aprender e de conhecer novos saberes (SILVA; RIBEIRO, 2018).

Os espaços diversos que compõem a paisagem dos territórios da escola devem e podem proporcionar as crianças - sujeitos sociais em formação, atores de sua própria vida - conhecimentos e oportunidades para que possam viver conviver, produzir e trabalhar, dando sentido às suas vidas.

Sem esquecer que no contexto atual, não se alcançam estes objetivos tão somente pela ótica de uma 'educação para o trabalho', mas também e paralelamente por uma ótica de 'educação pelo lazer' e/ou de 'educação por meio do lazer' num movimento que podemos localizar nestes estudos como 'lazer-educação', pois é perceptível que a educação está intimamente imbricada no lazer, assim como o lazer está permeado pela educação numa processualidade mútua de situações e acontecimentos.

Marcassa (2004) concebe o lazer como um "espaço de educação constante" por promover também o desenvolvimento pessoal e social e se constituir em instrumento de desenvolvimento da humanidade, "pois toda experiência de lazer se constitui no e pelo universo da produção simbólica da humanidade" (p. 4).

Christianne Luce Gomes (2003, 2008, 2010, 2011) nos remete a refletir e entender o 'lazer' como 'necessidade humana' e como 'dimensão da cultura' caracterizada pela vivência lúdica de manifestações culturais no tempo/espaço social da experiência humana.

Gomes e Faria (2005) esclarecem que a cultura pode ser entendida por um prisma antropológico, onde ela própria pode ser compreendida como um sistema simbólico específico da experiência humana.

Tratar a cultura como sistema simbólico implica uma ênfase na codificação da realidade. Assim a cultura torna 'pensável' e a experiência humana, a institui, e não apenas a representa (...). A noção de cultura pode transformar 
nossa compreensão do mundo, nosso modo de agir e de interpretar a realidade (GOMES; FARIA, 2005, p.14).

A educação, quando acolhe as experiências de lazer, tem como intenção formar o sujeito social - criança - para que experimente e viva o seu tempo disponível de forma cada vez mais positiva, mais construtiva, sendo um processo de desenvolvimento onde a criança amplia o conhecimento de si, do outro, das formas de lazer e das relações do lazer com a possibilidade do brincar e aprender, que irá constituir a sua vida no grupo social.

Por tanto, o 'lazer-educação' pode/deve ser considerado como um processo significativo da vida diária da criança nos territórios da escola, nesse sentido é necessário oportunizar o lazer para se aprender com suas possibilidades e vivências.

A relação possível entre 'educação' e 'lazer' orienta-nos a pensar a possibilidade da junção 'lazer-educação', já que tal associação pode contribuir com o processo de ensino-aprendizagem da/na escola, uma vez que há tempos o lazer que educa é lugar identificável de intencionalidade e formação educacional. Se 'educa-se' pelo lazer ou, por meio dele, porque não considerar o poder de alcance da manifestação do lazer e da educação, do 'lazer-educação'.

Nesse sentido, seria adequado considerar a importância do aproveitamento das ocupações, equipamentos e espaços de lazer como instrumentos auxiliares da educação. Pensamento que também corrobora com a intencionalidade de identificar/mapear espaços de lazer, no território social da/na Escola.

Pois na Escola o sujeito social - criança, ao participar e construir atividades em espaços de lazer e educação nesse território pode desenvolver-se de forma individual, ou socialmente no coletivo de crianças, condições indispensáveis para garantir uma participação mais efetiva na constituição de necessidades e aspirações de ordem individual, familiar, cultural e social. 
A criança pode aprender a ser, a viver e a conviver em sociedade para tecer, participar e escrever sua história possível. E é justamente essa nossa ideia, repensar os territórios da/na Escola como espaços localizáveis de práticas sociais, de práticas de/para o lazer da infância, e consequentemente de/para o 'lazer-educação'.

A educação e o lazer, ou a educação e o tempo livre da/na escola, sendo mais abrangente, com a intenção de formar o sujeito social - criança - para que ela experimente e viva o seu tempo disponível de forma livre e positiva, sendo um processo de construção por meio do qual a criança amplia o conhecimento de si, do outro, do lazer e das relações possíveis entre o lazer, os brincares e as aprendizagens, que irão constituir a sua vida no grupo social.

O 'lazer-educação' pode ser considerado como um processo significativo da vida diária da criança nos territórios da escola, nesse sentido é necessário oportunizar o lazer, e ensinar através de suas práticas, para que assim, se aprenda com suas possibilidades, vivências e experiências.

O lazer e os brincares podem compor significativamente o escopo de formação, desenvolvimento e construção das crianças. Nesse sentido, o convite é para lançar olhares para o deleite dos 'brincares', para a criança que se movimenta no deleite do 'lazer' das e nas infâncias e que brincam e se constroem no relevo desses espaços e territórios identificados na paisagem construída pela escola e em toda sua territorialidade.

Mais não olhares comuns e desatentos. Olhares de minúcias, que buscam a percepção de que a criança na escola se reconstrói socialmente, culturalmente e historicamente a partir das vivências experimentadas em grupo. Vivencias estas permeadas por marcadores sociais hegemônicos como classe, gênero, geração, etnicidade e etc... 
Segundo Pires (2007):

A infância deve ser entendida como uma construção social. A infância é uma variável da análise social. Ela não pode ser separada das outras variáveis, como classe, gênero ou etnicidade. As crianças devem ser vistas como ativas na construção e determinação de suas próprias vidas, na vida daqueles que cercam e das sociedades onde vivem (PIRES, 2007, p.27).

Dessa forma 'o lazer e os brincares', elementos de produção das infâncias, se tornam variáveis de análises de construções sociais, e não podem ou devem ser entendida tão somente como diversão ou maneira de uma criança se comportar, ou apenas se entreter.

Podem e devem ser compreendidos, como uma possibilidade educacional de aprendizagem cultural e de transformação da realidade, pois o 'ato de brincar' no tempo/espaço de lazer, possibilita reconhecimentos baseados numa conotação crítica e transformadora do processo do aprender e da aprendizagem.

\section{Os Brincares e o Lazer-Educação das Infâncias}

O brincar ou brincares, gerados pela interação cultural que se estabelece, é uma manifestação que alicerça a educação do 'ser' que se constrói, se constitui e se desenvolve nas infâncias para as relações sociais que irão se estabelecer na história e nas práticas culturais da vida cotidiana, alimentando-as e sendo por elas alimentado, nesse sentido o "lazer ganha dimensão e valor social" (PRONOVOST, 2011) por meio do brincar.

O brincar - produção histórica, cultural e um direito humano - é um importante meio de aprendizagem "crítica" social, na qual as tensões, os conflitos e as demais dimensões da realidade social manifestam-se, representando um campo privilegiado de promoção do desenvolvimento humano [...] (OLIVEIRA, 2007, p.133). 
Compreendido como prática social entrelaçado de cultura ${ }^{5}$, o brincar é uma manifestação que possibilita a educação do 'ser criança', que se constrói, se constitui, aprende e se desenvolve na multiplicidade das infâncias e nas relações sociais que se estabelecem na história e na cultura de lazer da vida desse sujeito social - criança.

Sendo cultura, o lazer é, pois, produto humano construído por meio de processos que se constituem a partir de valores, saberes, motivações e desejos de cada sujeito, influenciados pelos sentidos e significados que os mesmos atribuem as suas experiências. Processos localizados, uma vez que cada construção cultural depende do contexto social onde se realiza, do cotidiano onde os sujeitos criam as técnicas corporais próprias de sua cultura e seus modos específicos de lidar com os limites de tempo, lugar (...) (GOMES; PINTO, 2009, p. 98).

É por isso que trataremos tanto os 'brincares' quanto o 'lazer' como uma dimensão da cultura, pois a sua vivência e experiência e todo conhecimento que advém deles, podem produzir aprendizagens, saberes, novos saberes, significação e ressignificação do próprio contexto sociocultural da criança, e em sua experiência de vida.

Os brincares e o lazer podem ser então, compreendidos como processos culturais que se estabelecem e resultam em aprendizagens e conhecimentos ao longo das experiências e vivências de cada criança, pois nessa experimentação, produzem, constroem, desconstroem e reconstroem estes conhecimentos que são desdobrados, revividos e transformados em saberes, e/ou 'novos saberes' e 'novas experiências', o que compreendemos como acontecimentos de inflexões de aprendizagem.

E para compreendermos tanto a criança - nosso sujeito social em foco - quanto às infâncias que podem a constituir, vamos considerar nesses estudos, que toda 'forma de brincar' de uma criança ou grupo, pode compor o campo e a dimensão do 'fenômeno

\footnotetext{
${ }^{5}$ De acordo com Eagleton (2005), a cultura pode ser entendida como o conjunto de valores, crenças, costumes e práticas que caracterizam o modo de vida de determinado grupo social. Esse conjunto possibilita ao indivíduo inserir-se e interagir em seu grupo social, pois the permite negociar "maneiras apropriadas de agir em contextos específicos" (p. 55). Assim, a cultura inclui aquilo de que vivemos e aquilo para o que vivemos, como "afeto, relacionamento, memória, parentesco, lugar, comunidade, satisfação emocional, prazer intelectual” (p. 184).
} 
do lazer', pois toda criança que brinca produz culturalmente a existência do seu momento e manifestação de lazer, de uma forma ou outra, intencional ou naturalmente, individual ou coletivamente.

Brincando a criança, entende seu mundo, e se percebe no mundo no momento em que aprende e elabora possibilidades de ser e de estar no tempo e no espaço que ela própria apropria para experimentar a vida por necessidade de compor sua história.

Desta forma, trataremos aqui, segundo o que nos instiga a pensar Gomes (2008, 2010, 2011), o 'lazer' como necessidade humana fundamental, e como produção cultural caracterizada pela vivência lúdica dessas manifestações no tempo/espaço social, sendo satisfeita de múltiplas formas na vida do sujeito social - criança - pois se constituí nessa produção de acordo com "as peculiaridades do contexto histórico e sociocultural no qual é desenvolvido, por isso, precisa ser tratado como um fenômeno social, político, cultural e historicamente situado" (p.33).

De acordo com Gomes e Faria (2005):

O lazer deve ser pensado no campo das práticas humanas como um emaranhado de sentidos e significados dialeticamente partilhados nas construções subjetivas e objetivas dos sujeitos, em diferentes contextos de práticas culturais, sociais e educativas (p.33).

De acordo com esses pensamentos, "o lazer constitui-se na articulação de três elementos fundamentais: a ludicidade, as manifestações culturais e o tempo/espaço social” (GOMES, 2011, p.34)

Constituído conforme as peculiaridades do contexto histórico e sociocultural no qual é desenvolvido, o lazer implica "produção" de cultura - no sentido da reprodução, construção e transformação de práticas culturais vivenciadas ludicamente por pessoas, grupos, sociedades e instituições (GOMES, 2008, p.149).

Essas ações são construídas em um tempo/espaço social, dialogam e sofrem interferências das demais esferas da vida em sociedade e nos permitem ressignificar, simbólica e continuamente, a cultura e o lazer (GOMES, 2008; 2010). 
A criança que brinca e usufrui do lazer e de sua ludicidade, se insere no tempo e no espaço social em que vive, se insere e é inserida no grupo que a cerca e que compõe sua sociabilidade, pois é instigada pela experiência e vivência com esse grupo a reconstruir e problematizar a realidade percebida, ressignificando assim, o mundo onde está inserida e os espaços e territórios que ela pode ocupar no relevo social (SILVA; RIBEIRO, 2018).

“A infância é o tempo em que a criança deve se introduzir na riqueza da cultura humana histórica e socialmente criada" (MELLO, 2007, p. 90). Com toda certeza, podese afirmar que um desses tempos/espaços do relevo social é exatamente o da instituição educacional 'escola'.

Pois esse espaço segundo Gilles Pronovost (2011) é oportunizado, tanto para uma cultura científica mínima e experiência de aprender, quanto para o tempo livre para o lazer, cabendo assim a instituição escola fazer emergir em seu tempo, espaços e atividades; práticas culturais que promovam o desenvolvimento do sentido de autonomia, de criatividade, favorecendo a reflexão pessoal, a expressão e ampla variedade das experiências humanas, garantindo desenvolvimento integral e valorização pessoal.

É preciso, então, considerar as funções educativas que a escola pode praticar fora de seu campo tradicional de ensino, assim como as dimensões educativas presente na cultura, de democratização da cultura (...) que será feita a partir da escola (PROVONOST, 2011, p.121).

Por meio do brincar fora do campo tradicional de ensino, das práticas hegemônicas de ensino, a criança se apropria culturalmente do fenômeno do lazer e de seus espaços possíveis, elabora e recria seu contexto de vida, reinventa o seu mundo a partir do que é levada a aprender com ele na própria escola, que se torna campo de possibilidades para se aprender. 
É pensando exatamente nas oportunidades do campo de aprendizagem da escola, em espaços não tradicionais normatizados e de práticas não hegemônicas dentro dos territórios da própria instituição educacional, que surge o pensamento que nos permite refletir e compreender a dimensão educativa do lazer como um 'espaço outro'.

Espaço onde por meio dos brincares e sua diversidade, a criança se apropria do fenômeno do lazer e de seus lugares possíveis, elabora e recria seu contexto de vida, reinventa e ressignifica o seu mundo a partir do que é levada a aprender com ele.

De acordo com Gomes e Elizalde (2012):

O lazer não é um fenômeno isolado e se manifesta em diferentes contextos de acordo com os sentidos e os significados culturalmente produzidos/reproduzidos pelos sujeitos em suas relações com o mundo. $\mathrm{O}$ lazer participa da complexa trama histórica-social que caracteriza a vida na sociedade, e é um dos fios tecidos na rede humana de significados, dos símbolos e das significações (p.82).

O lazer no contexto social da formação do sujeito constitui-se na relação dialógica com outros campos no cotidiano da vida e do conviver (GOMES e ELIZALDE, 2012).

Um desses campos é exatamente a 'Educação', parte integrante da constituição da sociedade.

O lazer, a diversidade das formas e manifestações dos brincares e os espaços possíveis de aprendizado identificados nos territórios da escola, se engalfinham e se entrelaçam cotidianamente, na tentativa de reconstruir e redimensionar a constituição do sujeito social ‘criança' de forma rizomática, sem início, fim ou uniformidade definida. Assim, é importante considerar que "não é possível se entender o lazer, isoladamente, sem relação com outras esferas da vida social. Ele influencia e é influenciado por outras áreas de atuação, numa relação dinâmica” (MARCELLINO, 2012, p.15). 
Desse modo, o brincar se destaca na dimensão cultural do lazer social, o compõe, o complementa, instiga e se torna vetor de educação e dos processos de aprendizagens e aquisições de novos saberes.

Pois os brincares para as infâncias, assim como a manifestação do lazer para sociedade, é uma necessidade que se faz humana. Desse modo, o brincar se engalfinha com o lazer e ao mesmo tempo, com a educação, e pode ser compreendido então, diante dessa relação processual, como 'lazer-educação'.

\section{Traçando Rotas, Linhas e Construindo Possibilidades Metodológicas}

A cartografia, metodologia de pesquisa proposta para desenhar estes estudos, foi à proposta por Gilles Deleuze em parceria com Félix Guattari $(1977$; 1996; 1997) e quando deslocada para o movimento de uma pesquisa pós-critica, parece soar como "uma espécie de tecnologia de reconsideração das significações dominantes" (GUATTARI, 1988, p.175). "Uma cartografia desliza as noções essenciais de objetos de pesquisa que estão em algum lugar desde já e para sempre” (OLIVEIRA, 2012, p. 284).

Cartografar "implica alguma coisa que violenta o pensamento, que o tira de seu natural estupor, de suas possibilidades apenas abstratas" (DELEUZE, 1998, p. 56).

É com esse pensamento que se adotou a cartografia como princípio dos métodos nesses estudos, por entender que as infâncias se constituem por vida que se constrói, reconstrói, que pulsa, que corre, desbrava, avança percorre e transcorrem múltiplos caminhos, lugares, locais, sítios, territórios e espaços dentro de 'espaços outros' perfeitamente identificáveis, localizáveis na intenção da investigação.

Nessa direção, a cartografia nos direciona como:

Uma prática geográfica de acompanhamento de processos em curso [...] se oferece como trilha para acessar aquilo que força a pensar, dando-se ao pesquisador, como possibilidade de acompanhamento daquilo que não se curva à representação. [...] Convoca [o pesquisador] para um exercício 
cognitivo peculiar, uma vez que, estando voltado para o traçado de um campo problemático, requer uma cognição muito mais capaz de inventar o mundo (AMADOR; FONSECA, 2009, p.31).

Nesse sentido, as infâncias, seus espaços e territórios, não podem ou devem ser reduzidas a mero 'objetos' de uma simples representação, pois o que representam é maior do que se pode se objetivar no momento investigado, pois muda com a fluidez e a velocidade do desenvolvimento que se pretende alcançar com as formas de aprender os saberes do contexto vida.

Segundo DOS ANJOS (2013) numa cartografia “o objeto de pesquisa não preexiste, vai sendo produzido à medida que a investigação acontece" (p.25), à medida que o/a pesquisador/a é tocado pela experiência e vivência.

Desta forma, mapear e territorializar a criança no movimento do brincar das infâncias nos territórios da escola para alicerçar uma nova possibilidade de educar a infância, poderá redirecionar processos de reconhecimento e aprendizagem numa movimentação cartográfica do local - espaços - destes acontecimentos, procedimento metodológico que se preocupa com todo entorno da pesquisa, desde a produção do conhecimento e epsteme ${ }^{6}$, perpassando por toda sua processualidade em si.

Ao analisar a criança que se constitui e brinca na infância em territórios de lazer da/na escola, não se pretende traçar uma única rota, ou identificar um único caminho, mas recriar e compreender que as infâncias concebem de diferentes maneiras e trajetórias seu corpo vivido, sentido e experimentado em cada espaço do território, por tanto, muitos serão os caminhos possíveis.

Uma hipótese é a identificação de múltiplas linhas e espaços mapeando as trajetórias e rotas que compõem a interpretação do comportamento da criança que

\footnotetext{
${ }^{6}$ Epsteme, segundo a visão e nomenclatura de Michel Foucault (1967), no livro As palavras e as coisas, é um conjunto das regras e dos princípios, predominantes num determinado período histórico, que possibilitam que certas coisas - e não outras - sejam ditas, configurando campos particulares de saberes.
} 
brinca na infância, do seu corpo que aprende nas experimentações das infâncias, diante da constituição social, histórica e cultural presente nas práticas corporais do 'brincar e lazer'.

Esta identificação nos parece: "um exercício de dispor o trabalho de pesquisa como uma operação de invenção da vida, de virtualização da existência, de potenciação do estar no mundo da educação, transfiguração das coisas, das palavras, dos territórios educacionais" (OLIVEIRA, 2012, p.286).

Reconhecer a criança que brinca nas infâncias, será apostar na, corporeidade ${ }^{7}$ sentida enquanto fenômeno complexo de manifestação e capaz de manifestar o aprender e também a aprendizagem de muitas formas diferentes, respeitando a individualidade de cada um/a, respeitando a percepção da existência de cada um/a, sem formas fixas, estáticas, acabadas para se perceber enquanto corpo que aprende em tempos/espaços/territórios.

A cartografia de espaços e territórios por onde os corpos das crianças brincam, permite exatamente isto, reforçar a hipótese de: reconhecimentos de lugares de apropriação e elaboração de conhecimento, saberes e acontecimentos de inflexões de aprendizagem em espaços não hegemônicos, em tempos/espaços/territórios educacionais 'outros, destinados aos brincares e ao lazer das infâncias nos territórios da escola.

Para tanto, foram utilizados os seguintes instrumentos investigativos: A técnica e experiência da 'observação participante' do e no brincar, pois permite investigar tanto os saberes, quanto as práticas na vida social e reconhecer as ações e as representações

\footnotetext{
${ }^{7}$ A corporeidade define o ser humano como ser complexo, estando todas as qualidades e dimensões pertencentes ao humano enraizadas em seu corpo. É por meio do corpo que podemos identificar a individualidade, a existência e o ser. (...) É nesse sentido que buscamos a compreensão da complexidade humana, tanto no nível individual e social quanto no cósmico. Portanto, corporeidade é o resultado complexo da articulação do universo físico (phisys), do universo da vida (bios) e do universo antropossocial (FREIRE, 2004, p.61).
} 
coletivas na vida humana, se engajando em uma experiência de percepção de contrastes sociais, culturais e históricos (ROCHA \& ECKERT, 2008).

Registros dos acontecimentos em 'diário/caderno de campo' por permitir que num primeiro momento, o pesquisador anote tudo para depois conseguir fazer um procedimento mais analítico do que escreveu (WINKIN, 1998).

Utilização de 'imagens fotográficas' dos espaços nos territórios escolares, por permitir expor, discutir e demonstrar as relações entre os acontecimentos e as imagens produzidas a partir dele (SONTAG, 2004), e por fim 'análise crítica do discurso' segundo os pressupostos foucaultianos, trajeto onde se identificou 'enunciados' produzidos e registrados no decorrer das práticas sociais possibilitadas pelo brincar da infância na escola - 'as falas das crianças' - em momentos e diálogos específicos do/no 'brincar e lazer' na escola nos espaços e territórios destinados as infâncias.

Sempre discorrendo sobre alguns aspectos importantes na movimentação da pesquisa e da possibilidade de geração de dados com as crianças, tais como: a entrada no campo e o consentimento para estar lá; a ética na pesquisa com crianças; a problematização da produção e da análise dos dados; e os instrumentos utilizados na pesquisa com crianças.

O primeiro aspecto trata sobre os termos e autorizações para realização da pesquisa, inicialmente com a obtenção do - Termo de Consentimento Livre e Esclarecido (TCLE) - assinado pelos adultos envolvidos com as crianças (direção, pais/responsáveis), antes de iniciar a pesquisa de campo

E do consentimento, que é dado diretamente pelas crianças o - Termo de Assentimento Livre e Esclarecido (TALE) - e que envolve um relacionamento de respeito, confiança e cumplicidade estabelecido entre estas e o pesquisador. 
O segundo aspecto envolve a ética na pesquisa com crianças, a qual não envolve apenas a "ética prescritiva" - dos códigos, dos consentimentos, das autorizações, das permissões para estar ali - mas também a "ética dialógica" - caracterizada pela capacidade interacional do pesquisador com os pesquisados (SPINK, 2000).

A ética na pesquisa com crianças perpassa todos os acontecimentos do estudo, desde o consentimento para estar no grupo, até o momento de interpretação, análise e publicação dos resultados da pesquisa.

O terceiro aspecto envolve a problematização da ideia de se 'produzir os dados', pois nosso movimento não se preocupa em apenas 'coletar dados' no trabalho de campo, mas de produzi-los e construí-los a partir da interação com os sujeitos sociais - crianças - e seus contextos no território da escola.

Lançando mão destes instrumentos investigativos e considerando estes aspectos importantes para inserção no campo de pesquisa, foi também importante considerar as diferentes maneiras e expressões de cada criança participante, como palavras, gestos, risos, choros, aproximações, distanciamentos, jogos, brincadeiras, brinquedos, criações, produções, imitações, conflitos, entre outras nuances de acontecimentos, que poderiam significar e sinalizar algumas estratégias para compreendermos as 'culturas infantis' e o 'modo' como as crianças da/na escola, brincam, aprendem, constroem e vivem as suas vidas nos territórios da escola.

Para isso, foi estimado um processo permeado por sensibilidades, para que, em decorrência, também pudéssemos ser capazes de compreender e de construir 'elos de sentidos ${ }^{\prime 8}$ para interpretar a realidade percebida.

\footnotetext{
${ }^{8}$ Chamaremos de elos de sentido os pontos convergentes, para se interpretar, analisar e conectar partes distintas dos acontecimentos, mas, ao mesmo tempo, articuladores de partes da realidade percebida, permitindo a verificação e interpretação desses acontecimentos no tempo/espaço social da criança, percebidos na escola e, desta maneira, chegar a uma denominação possível aos espaços investigados e identificados no decorrer da geração dos dados empíricos.
} 
Elos de sentidos, advindos de processos de indução pela experimentação da realidade que permite, na processualidade do mapeamento, começar a traçar e desenhar mapas identificáveis sobre os acontecimentos nos espaços do território desbravado estabelecendo a construção cartográfica.

Para tanto, o movimento da pesquisa em campo foi à aproximação e inserção do 'eu pesquisador' junto a cada grupo de crianças participantes dos processos de observações que iriam decorrer a cada encontro e possibilidade do 'estar junto' no tempo/espaço social de lazer da criança da/na escola.

Essa primeira aproximação acontecia com a chegada à sala de aula, local na/da escola onde, inicialmente, encontrava com as crianças, para depois nos deslocarmos para os espaços de apropriação e utilização do tempo livre ao lazer.Momento denominado por nossas sensações e necessidades de 'estar junto' - para estabelecer vínculos, ganhar a confiança e firmar, por meio de uma postura amistosa e lúdica, a parceria necessária à aceitação e inserção no/do grupo de crianças da escola e de cada instituição educacional - território escolar - que serviu como paisagem de nossas verificações.

Nos primeiros encontros, apresentações, conversas, brincadeiras, conquistas e a busca de estabelecer confiança, permearam a intencionalidade do 'estar junto' e de pertencer gradativamente a cada tempo de aceitação e proximidade estabelecida com o grupo pesquisado, além da possibilidade de registrar todos os acontecimentos significativos, sendo importante momento para investigar o conhecimento e percepção das próprias crianças sobre as temáticas de nossas verificações: a percepção do lazer na escola, do tempo livre da escola, dos brincares na/da escola, das aprendizagens por meio do movimento do brincar nos espaços/tempos que estamos considerando como 
situações e manifestação de 'lazer-educação' nos territórios da escola e que também podiam promover inflexões de aprendizagens.

Neste estudo cartográfico, foram/são utilizados então, caminhos investigativos, desenhados a partir das observações, do diário/caderno de campo, das imagens fotográficas dos espaços mapeados nos territórios, identificados e utilizados, e dos discursos e falas enunciadas de maneira formal e informal pelas crianças, os quais podem ser considerados importantes instrumentos de investigação, geração/produção de dados para garantir a obtenção de nosso objetivo traçado.

\section{Espaços Heterotópicos nos Territórios da Escola}

O filósofo francês Michel Foucault (1967) já nos convidava a refletir sobre "outros espaços", quando apontava que a atualidade ou em suas palavras "a época atual, seria talvez de preferência a época do espaço" de espaços conhecidos, explorados, mas também de outros espaços prontos a serem explorados, ou de um 'espaço outro' localizável dentro do próprio território do espaço.

Foucault chamou de heterotopia a invenção e criação de espaços outros. Esta forma de pensar nos foi apresentada durante a Conferência que o autor realizou no Círculo de Estudos Arquitetônicos em 1967, denominados 'Outros Espaços', e o marcante em seus pensamentos é a situação de que, cotidianamente, vivenciamos e experimentamos a época do espaço e de 'espaços outros'. Segundo Foucault (2009):

\footnotetext{
Estamos na época do simultâneo, estamos na época da justaposição, do próximo e do longínquo, do lado a lado, do disperso. Estamos em um momento em que o mundo se experimenta [...] menos como uma grande via que se desenvolveria através dos tempos do que como uma rede que religa pontos e que entrecruza sua trama (FOUCAULT, 2009, p.411).
}

De acordo com seus escritos o espaço não pode ser simplesmente considerado utópico ou lugares imaginados e que não se encontram geograficamente localizáveis, é 
preciso redimensionar o pensamento para sua compreensão como sendo 'heterotopia', ou seja, utopias localizáveis nos espaços reais.

Para Foucault, existem os espaços reais, concretos, lugares que nos situamos e existimos, lugares instituídos, mas falar de heterotopia, não significa falar desses lugares, significa falar de outros espaços, que coexistem com os lugares reais e espaços instituídos. Significa falar de "lugares que se opõem a todos os outros, destinados, de certo modo, a apagá-los, neutralizá-los ou purificá-los” (FOUCAULT, 2013, p. 20).

A invenção de espaços outros, ou heterotopia, propõe pensar e refletir sobre os outros espaços que coexistem com o espaço instituído, pois são:

\begin{abstract}
Lugares reais, lugares efetivos, lugares que são delineados na própria instituição da sociedade, e que são espécies de contra posicionamentos, espécies de utopias efetivamente realizadas nas quais os posicionamentos reais que se podem encontrar no interior da cultura estão ao mesmo tempo representados, contestados e invertidos, espécies de lugares que estão fora de todos os lugares, embora eles sejam efetivamente localizáveis. Esses lugares por serem absolutamente diferentes de todos os posicionamentos que eles refletem e dos quais eles falam (...) chamarei em oposição às utopias, de heterotopias (FOUCAULT, 2006, p.415).
\end{abstract}

Para Foucault, o modo como reconhecemos o espaço, de como o objetivamos em nossos pensamentos, ideias e teorias não é uma inovação, pois o espaço, na sua experiência de existir e territorializar, produzem uma história, não sendo possível desconsiderar o entrecruzamento vital entre tempo e espaço.

Podendo-se dizer que a história do espaço, é composta por um conjunto hierarquizado de lugares: lugares sagrados e lugares profanos, lugares protegidos e ao contrário lugares abertos e sem defesa, lugares urbanos e lugares campestres; para a teoria cosmológica havia os lugares supra celestes opostos aos celestes, e estes por sua vez, se opunham aos lugares terrenos, ou seja, era esta hierarquia, esta oposição que caracterizava o espaço de localização (FOUCAULT, 1967).

Foucault (1967) chama a atenção para aqueles espaços que tem a curiosa propriedade de estar em relação com outros, mas de tal sorte que sobre estes estão 
suspensos, neutralizam, ou invertem o conjunto de relações que se encontram ali, entre eles. "Espaços que de alguma maneira estão em ligação com todos os outros, mas que contradizem os outros “modos" de ocupação destes lugares" (POCAHY, 2006, p. 95).

Cláudia Ribeiro (2008) aponta ainda que as heterotopias podem ser entendidas como lugares reais que se efetivam ao mesmo tempo em que se contrapõem ao espaço instituído, coexistindo com ele dessa forma. "Numa heterotopia, entramos num lugar outro, que pode nos remeter a muitos outros lugares" (RIBEIRO, 2008, p.2).

Lugares outros, heterotópicos, que mesmo identificáveis estão fora do instituído e em oposição a ele, numa contraposição ao pensamento que alcança e normaliza os acontecimentos, ao mesmo tempo em que compõe, neutraliza, invertem ou intervém em tais acontecimentos do espaço instituído.

As ideias no entorno dessa maneira de pensar e reconhecer os territórios e os espaços que o compõe nos permite refletir e compreender os espaços educativos do território da escola como um "espaço heterotópico" de aprendizagem, ou seja, "outro espaço’ para aprender (SILVA, 2013).

Nesse sentido, os espaços destinados aos brincares e lazer das infâncias, dentro do cenário atual da Educação e dos territórios da Escola, se aproximam de um 'espaço educativo outro', de um 'espaço heterotópico para o lazer' destas infâncias que aprendem em um ‘outro espaço’ que não o instituído.

Sílvio Gallo (2007) já deslocava o conceito de heterotopia para o espaço escolar, para o espaço de aprendizagens, questionando como produzi-la no cenário da educação, já que este espaço é planificado, organizado, disciplinado, controlado.

Produzir heterotopias aí, significa inventar outros espaços, para além da organização e do controle instituído (...) significa engendrar novos espaçostempos que instituam relações pedagógicas diferenciadas. E que suscitem acontecimentos (GALLO, 2007, p. 100). 
Mas o que significa suscitar acontecimentos na educação?! Segundo Gallo (2007), seria abrir-se para o que acontece em sala de aula, ou nos outros espaços escolares, para além do planejado, do planificado, dos objetivos definidos de antemão.

Seria atentar mais para a trajetória do que para o ponto de chegada, pensando os tempos educacionais como vivência do instante e não como planificação milimétrica das atividades. Nesse sentido devemos:

\begin{abstract}
Utilizar o conceito foucaultiano de heterotopia para pensar o cotidiano escolar como um outro espaço, um outro lugar, em que outras relações sejam possíveis, em que a criação seja possível. Não local de permanência, mas lugar de passagem, entre - lugar. Tomar o cotidiano escolar como heterotopia, como um outro lugar distinto dos espaços sociais, mas também como um outro lugar em relação à escola instituída, estabelecendo relações outras, instituintes (GALLO, 2013, p.10).
\end{abstract}

Nestas reflexões percebemos então que este deslocamento é possível, e que os brincares e lazer das infâncias nos acontecimentos dos territórios da escola, surge como um 'outro espaço' educativo na própria geografia da escola.

Espaço de heterotopia ou espaço heterotópico para que ocorra aprendizagens e aprendizagens de novos saberes - inflexões de aprendizagem - por justapor o espaço que se destina ao brincar para aprender, ao lazer para fruição e satisfação dos modos de aprender dentro do processo de ensino-aprendizagem dos territórios educacionais da escola.

É um outro espaço para a aprendizagem que a criança se apropria, um espaço fora da normalização, da institucionalização, da padronização das instituições de ensino, das práticas hegemônicas de se educar, de uma nova história tecida em espaços dentro do próprio território experimentado no tempo e em seus entrecruzamentos (SILVA, 2013).

Lugares possíveis, de fuga, mas também de possibilidades reais, interligando educação, os brincares e o lazer das infâncias, a aprendizagem e inflexões de aprendizagem decorrentes. 
Contrapondo-se a normalidade do ensino, ou com o qual o ensino apenas se reproduz pela possibilidade de reconstruções da forma de brincar e de aprender num espaço educacional outro, pertencente ao próprio lugar da Educação nos territórios da Escola, mas que se concretiza em outros modos de estabelecer este lugar de aprendizagens e de novos saberes.

Compreender a ideia de heterotopia como lugar outro, que contempla uma educação transformadora, é considerar os espaços outros dentro do próprio território/espaço/tempo, que nos remete a muitos outros lugares perfeitamente localizáveis (RIBEIRO, 2009) e de suas possibilidades e construções, que nos permite entender então que os brincares e lazer da infância podem ser considerados como "lugares que estão fora de todos os lugares, embora eles sejam efetivamente localizáveis.” (FOUCALT, 2009, p.415).

Levando-nos a também compreender que a partir deste entendimento, os espaços nos territórios da Escola são educacionais e não podem, e nem devem ser apenas considerados como espaços ou lugares utópicos, um lugar sem lugar, essencialmente ou estruturalmente irreal, mas espaços e lugares reais de contraposição, de heterotopias e acontecimentos imbuídos de transformação e práticas sociais.

Os espaços destinados aos brincares e lazer da infância, no processo educativo dos territórios da escola, podem ser considerados como um lugar que está fora de todos os outros lugares educativos, mas com possibilidades reais e concretas de aprendizados.

Espaços outros de reconstrução dos processos de aprendizagem, dos processos de ensino-aprendizagem, de ensinar e aprender, e de aprender a ensinar, um espaço outro de educar-se dentro da própria educação, um 'não' espaço educativo, marcado pelas inter-relações e interações do comportamento humano, espaço outro de transformação, "que conectados a todos os outros espaços abre caminho para 
transformação" (SWAIN, 2005, p. 340) permeada pela aprendizagem de forma significativa e situada.

Assim, os espaços de lazer dos territórios da escola, podem ser considerados na identificação de seu tempo/espaço de acontecimentos, como 'espaços outros' para os brincares e as aprendizagens dessa experimentação, se tornando assim, 'espaços heterotópicos para o Lazer-Educação’.

\section{Espaços Heterotópicos de Lazer que Possibilitam os Brincares e os Acontecimentos das Inflexões de Aprendizagem nos Territórios da Escola}

Trazer para a escola, seus lugares, e territórios, características que só a infância ou as infâncias podem descobrir e descobrem em sua processualidade de apropriação do espaço outro, é também possibilitar que essa infância, na representação de crianças da/na escola, sejam atores e autores de sua própria história de vida no mundo.

Neste sentido há de se considerar para estas verificações que as crianças da escola são sujeitos sociais constituídos na e pela cultura social do mundo que as cerca. Constituídas em tempos e espaços próprios, específicos para 'aprendizagens' e 'aprendizagens de novos saberes', portanto, nossa movimentação, transcende a possibilidade de tão somente pesquisar as infâncias ou a escola, para se 'produzir' junto com as crianças da escola, gerando a oportunidade de se verificar e reconhecer uma infância que 'produz conhecimento' nos lugares, tempos, espaços e territórios que são delas, e que são próprios. 


\section{Figura 1: Espaços que a criança descobre para brincar e brincando aprende.}

\section{Território Escolar I}

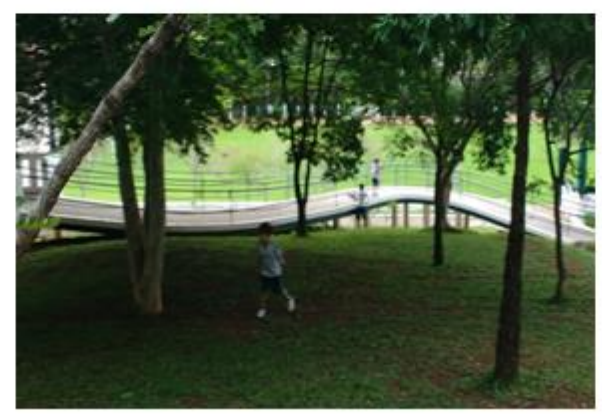

\section{Território Escolar II}

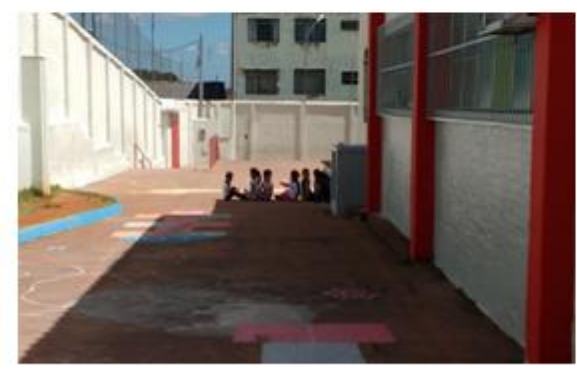

Território Escolar III

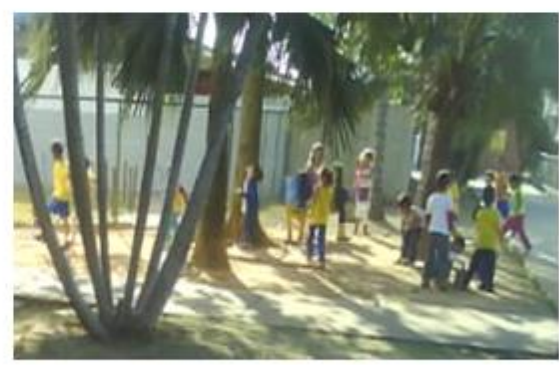

Fonte: Registro Fotográfico da Pesquisa

Nosso movimento essencial de pesquisa nesses três territórios escolares se dá em pesquisar com as infâncias, e não a partir delas, portanto, com as crianças da/na escola, de maneira ativa e efetivamente identificando possibilidades a partir dos olhares das próprias crianças frente as suas experimentações e descobertas de espaços diferentes dentro do próprio espaço determinado, observados e identificados em situações e acontecimentos lúdicos, também próprios da infância na escola, que descobrem a todo momento outros espaços dentro do próprio espaço que podem se apropriar.

Nesse sentido a maior intencionalidade, é que os mapeamentos, verificações e identificações que se configuraram, transcorressem por meio de processos de interação, socialização, integração e de trocas de saberes envolvendo tanto a figura do adulto professor/pesquisador, em seu movimento de observar e perceber a realidade da criança que brinca. Quanto do movimento advindo de sua participação e inserção no grupo de 
crianças, capazes de experimentarem, descobrirem, inventarem e escreverem novas histórias, descrevendo assim novos momentos e acontecimentos de aprendizagem, para além do que está aprendido ou instituído e normatizado pelos processos educacionais de ensino e aprendizagem - demarcados pelo 'currículo' da escola, pois elaborar, inventar e criar para as infâncias, também significa aprender coisas novas.

Buscando produzir identificações a partir dos espaços nos territórios da escola, que permitiram verificar o surgimento de novos saberes que aconteceram em espaços outros que as crianças descobriram, se apropriaram, escolheram e usaram para suas práticas sociais de forma criativa.

Práticas sociais, produzidas e/ou reproduzidas por uma infância que brinca ao mesmo tempo em que tenta compreender o mundo que as constroem e as constituem na distinta experiência do lúdico e da ludicidade que o lazer lhes confere em seu tempo livre na escola.

A ludicidade pode ser compreendida como uma necessidade que o sujeito social leva consigo por toda sua trajetória de vida. O lúdico e a ludicidade, dessa forma, são componentes necessários em todas as etapas do desenvolvimento e aprendizagem do ser humano, sendo um dos principais aspectos das práticas sociais responsáveis pela manutenção da sensibilidade e nutrição da alma humana (SANTOS, 2010).

Práticas sociais que a infância utiliza para criativamente demarcar seus espaços existentes e descobrir neles, maneiras de viver e conviver no grupo social em seu entorno, estabelecendo relações de proximidade por meio de manifestações lúdicas.

Prazer, alegria e diversão, são sentimentos que conduzem estas práticas sociais criativas, evidenciadas pela 'ludicidade' imbricada no lúdico do brincar; do corpo da criança que brinca e aprende no decorrer da infância que percorre, porque enquanto brinca, ela assimila as experiências vividas em sua realidade social, sendo que tais 
experiências são derivadas da interação da criança com outras crianças (SANTOS, 2010).

Manifestações da criança que se movimenta e movimentando-se, brinca, descobre e compartilha saberes e conhecimentos por meio das manifestações lúdicas. Segundo Massa (2015) uma "manifestação lúdica: é como a ludicidade se revela e se expressa, através do indivíduo. Faz-se conhecer sua presença através de diversas formas (sinais físicos ou atividades lúdicas)” (p.127).

A ludicidade amplia as alternativas proporcionadas pelos brincares e, por meio dessa possibilidade, cada criança constrói e reconstrói significados, pois sua imaginação a transporta para espaços diferentes, que lhes permite modificar locais, transformar lugares, criar situações e personagens, ressignificar objetos assimilando saberes por meio da representação. Ao brincar a criança sempre aprende coisas novas, reconhece novos saberes, e por meio do lúdico assimila os costumes e as particularidades do ambiente a sua volta (LEAL, 2011).

Segundo Curtis (2006), "brincar imaginativo", "brincar imitativo", "brincar criativo", "brincar cognitivo", "brincar de faz de conta", "brincar sócio dramático", seriam algumas possibilidades e nomenclatura para se dar as brincadeiras e jogos que permeiam os brincares das infâncias, conforme as próprias características observadas nos atos e ações das crianças.

Assim, compreendemos que dentre os muitos benefícios, o brincar ou brincares da infância pode contribuir para ampliar a experiência imaginativa e aumentar a criatividade, o que contribui para o seu desenvolvimento global, afinal "as crianças aprendem através do brincar" (CURTIS, 2006, p.48) e o "brincar é uma maneira útil de a criança adquirir habilidades - sociais, intelectuais, criativas e físicas" (SMITH, 2006, p. 26). 
Conhecimentos que por meio de práticas sociais estabelecidas, apreendidas e também reproduzidas, tornam crianças capazes de transformar o que se sabe, de mudar o que se sabia, de gerar novos saberes num movimento contínuo de 'inflexões de aprendizagem' que possibilita a educação do ser. Nesse sentido, é preciso considerar que quando se educa utilizando-se dos brincares deve-se valorizar sempre a cultura e a expressão infantil (KISHIMOTO, 2002).

É por intermédio dessa cultura da infância e do ato de brincar que a criança troca experiências com as outras crianças, assumindo personagens, criando e recriando situações imaginárias, ou vivenciadas que permitem transformar essa experiência em um aprendizado dinâmico e significativo (KISHIMOTO, 2002).

Que permitem acontecimentos de inflexões de aprendizagem no processo de aprender brincando. É o movimento do brincar no tempo/espaço de lazer onde acontecem as inflexões de aprendizagem, percebidas no decorrer da experimentação e do prazer em brincar na infância.

Sentimento que possibilita também perceber que 'novos saberes' são possíveis e se efetivam a partir das descobertas, individuais e coletivas, dos lugares, e na apropriação destes espaços pela criança que brinca nos territórios da escola.

É por meio da experiência do seu corpo, do movimento do seu corpo nos espaços, da percepção deste corpo da criança que se constrói no brincar da infância, e do corpo desta criança que se movimenta e brinca nos territórios da escola, que novos espaços para produção de saberes e novos saberes podem ser identificados, mapeados e cartografados.

E desta forma, desenhar novas composições de mapas diferentes dos já conhecidos. Desenhos que evidenciam a criança em movimento, e o movimento dos brincares da infância, em seu tempo livre, em espaços estabelecidos como de brincar no 
tempo/espaço desta criança, pois permitem diversão e, por conseguinte, garante o 'lazer' para a infância na escola, na experiência das atividades lúdicas.

Dessa forma, a união entre os conhecimentos e saberes adquiridos na vida cotidiana da criança e os transmitidos, adquiridos, surgidos pela criança que brinca no espaço/tempo da escola, é essencial para estabelecer um processo de aprendizagem significativo (TRETTEL; BATISTA, 2016).

É por isso que os processos educacionais que permeiam as infâncias se efetivam, ou podem se efetivar por meio da 'ludicidade', por meio do universo lúdico no entorno dos brincares, tempo/espaço tão presente e inerente a infância, que de uma forma ou outra, acabam por estabelecer conexões entre descobertas e significação do conhecimento.

Para que assim se busque a todo o momento, perceber e escutar as crianças com sensibilidade e muita seriedade, por meio de seus gestos ações, comportamentos, suas falas e discursos, por meio da identificação do seu movimento de brincar, dos jogos e brincadeiras acontecidos, e até dos brinquedos utilizados em seu tempo livre de lazer na escola, e de suas movimentações, negociações e enfrentamentos nas interações percebidas em suas práticas sociais que se estabeleciam a cada acontecimento. 
Figura 2: Espaços heterotópicos de lazer que possibilitam acontecimentos de inflexões de aprendizagem Território Escolar I

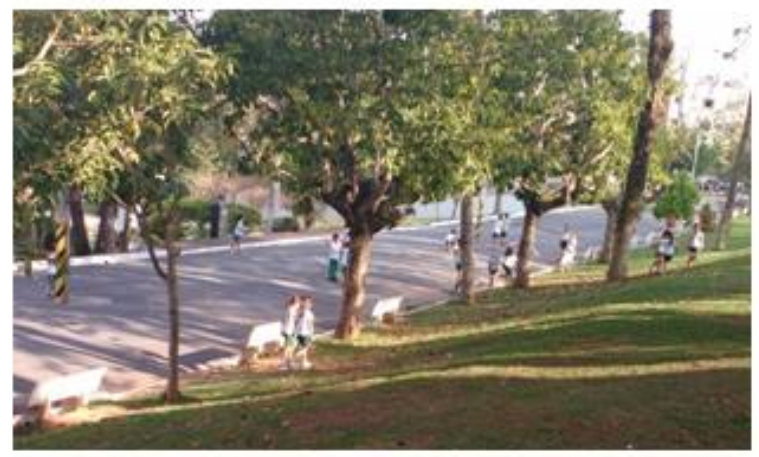

Território Escolar II

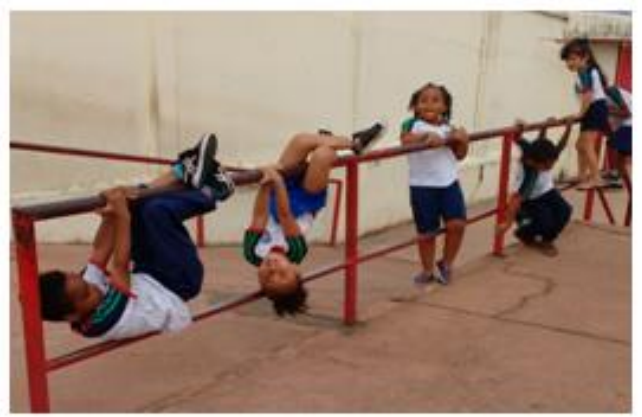

Território Escolar III

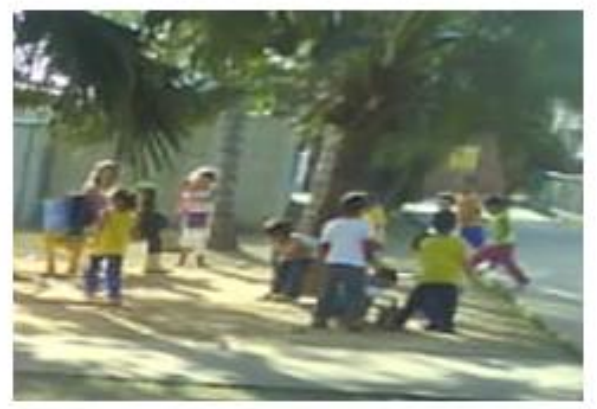

Fonte: Registro Fotográfico da Pesquisa

Desta forma, cada diferente maneira de expressão de cada criança participante, como palavras, gestos, risos, choros, aproximações, distanciamentos, jogos, brincadeiras, brinquedos, criações, produções, imitações, conflitos, entre outras nuances de acontecimentos, puderam significar e sinalizar algumas estratégias - elos de sentido - para compreender as 'culturas infantis' e o 'modo' como as crianças da/na escola, brincam, aprendem, constroem e vivem as suas vidas nos territórios da escola.

Elos de sentidos que permitiram no processo de mapeamento, traçar e desenhar mapas identificáveis sobre os acontecimentos do território desbravado estabelecendo a construção cartográfica. 


\section{Espaços de Lazer nos Territórios da Escola: O Desenho dos Mapas}

Gosto de brincar na escola (...). Na hora do brincar ou na hora do recreio, cada um pode escolher do que brincar... Pode escolher o jogo ou qual brincadeira vai fazer e participar, por isso é bom! Podemos ser o que quiser... Fazer o que quiser... E escolher onde... Tem muitos lugares bons na escola... 'Mas meninas e meninos tem que ser diferente'... [depois de uma pequena pausa]... Bom às vezes... Porque brincar junto também é legal...(Fala de uma Criança Participante - Diário/Caderno de Campo - Abril / Novembro 2018).

A intensidade dessa e de outras muitas falas registradas, nos remeteram a refletir sobre cada paisagem da pesquisa - Escolas e Territórios - observada e identificada ao longo de 30 encontros para 'estar junto' das crianças, compreendendo o que cada instituição educacional, delimitava e destinava como sendo tempo/espaço social livre para criança brincar na escola e em seus territórios e espaços foram unanimemente encontrados: a 'hora do recreio' e a 'hora do brincar'.

Tempo/espaço também percebido e reconhecido pelas próprias crianças como tempo livre, de lazer, nos territórios da escola, como tempo livre para livre escolha do brincar, tempo livre para a criança ser criança.

Em cada paisagem da pesquisa, variou-se de acordo com as necessidades da instituição uma média de permanência junto ao grupo de crianças que durou por volta de quase 04 meses de observações dentro dos semestres letivos (entre abril e novembro de 2018).

A movimentação no entorno de cada encontro para o 'estar junto' das crianças, consistia em estabelecer 'contato' e 'diálogos' possíveis, para 'observar' a apropriação e uso dos espaços no território da escola, e assim perceber o acontecimento dos brincares e as relações e socializações estabelecidas a partir das atividades manifestações lúdicas, de livre escolha (jogos e brincadeiras) da infância em seu tempo dito livre na escola.

Este processo de envolvimento e observação das crianças e suas relações tornaram possíveis 'registrar' em diário/caderno de campo, as práticas sociais que se 
estabeleciam (escolhas de espaços, negociações, combinados, conversas, etc.), bem como os discursos enunciados por meio das falas das crianças no decorrer das processualidades, diante das situações e acontecimentos, o que reforçou a ideia de acontecimentos das inflexões de aprendizagem.

As processualidades se davam em perceber a movimentação do brincar nos espaços de apropriação e uso dos territórios da escola, que podiam então ser identificados por elos de sentidos para subsidiar as investigações e interpretações possíveis mapeando os espaços dos acontecimentos.

E nos diálogos e conversas intencionais junto às crianças ou grupos de crianças para se perceber e interpretar os saberes advindos das relações estabelecidas, das problematizações de situações acontecidas, das manifestações e também mudanças de postura e comportamento da criança diante das negociações e combinados para 'fazer acontecer' o brincar.

Desta forma ousou-se identificar/verificar e sugerir os lugares possíveis para as aprendizagens e inflexões de aprendizagens manifestadas pela criança por meio de práticas sociais, delas próprias ou no processo de reprodução de suas vivências e experiências no momento do lazer, no momento do brincar.

Os 'elos de sentidos' subsidiaram nomear e desenhar no mapa, não só o espaço/tempo de apropriação da criança que brinca nos espaços e territórios da escola, mas também a representação destes na rica complexidade de experiências que constituem cada espaço.

Nesse sentido tais 'elos' constituíram-se pelas experiências percebidas e apresentam-se, a partir das observações, investigações e percepções do espaço como sendo representado pela criança e para ela como sendo: 
- Espaços de diversão: representando elos de sentidos que remetem a 'euforia do momento experimentado'.

Os 'espaços de diversão', são lugares que contemplam para a criança um estado ou sensação de divertimento, de entretenimento, de distração, de recreação, ou seja, sentimentos ligados a fruição do prazer em ser, em participar e arriscar-se, em criar, imaginar e fazer parte de algo, promovendo um estado de alegria e de satisfação interior na apropriação dos espaços eleitos.

- Espaços de aventura e desafios: representando elos de sentidos que remetem a 'superação de desafios e de limites'.

Os ‘espaços de aventura e desafio’ são espaços que contemplam para a criança o estado ou a sensação de emoção, do inesperado, da não certeza ou domínio do que virá pela frente, de ocorrências surpreendentes para a realidade vivenciada, de empreendimentos, de ousadia, e até de acontecimentos estranhos que provocam o aventurar-se em experimentar algo novo e desconhecido, algo desafiador.

Que contemplam o estado ou a sensação de superação de limites, de desafiar algo ou alguém, de provocar ou competir com alguém, de competição, de batalhar, de lutar, de se atingir algum resultado almejado, de superar expectativas.

- Espaços de passagem: representando elos de sentidos que remetem a 'transposição de lugares reais e do/no imaginário da criança'.

Os 'espaços de passagem' para as crianças, são espaços que contemplam o estado ou a sensação de passagem ou passar de um espaço a outro, de travessia ou de atravessar, de transpor-se ou transferir-se de um lugar a outro, de um espaço a outro que não aquele em que se encontra, ou seja, imbricados de sentimentos ligados a fruição do prazer em sentir e do desejo de se imaginar mudanças fictícias na realidade 
experimentada, promovendo um estado imaginário, ilusório e simbólico que criativamente possibilita satisfação em ser, estar, criar, imaginar e fazer.

- Espaços secretos: representando elos de sentidos que remetem 'ao que está escondido e longe do governo dos adultos'.

Para as crianças, os 'espaços secretos' são espaços que contemplam o estado e a sensação de coisas e situações ocultas, escondidas, em segredo, preservadas pelo esconderijo, pela sensação de se esconder, se esquivar, mesmo que momentaneamente da realidade vivida e estabelecida pelo mundo adulto, ou seja, sentimentos ligados a fruição do prazer em sentir-se secretamente oculto, em segredo e escondido dessa realidade, mesmo estando perfeitamente exposto a realidade.

Espaços apropriados ou de apropriação pelas infâncias, observados/identificados/mapeados na possibilidade de participação dos/nos acontecimentos que se configuraram em momentos onde as socializações das crianças se manifestavam e se efetivavam por meio das 'falas' - discursos enunciados - que determinavam todo acontecimento, como o estabelecer das regras e normas combinadas para os brincares, e por consequência no uso dos espaços nos territórios da escola.

Para cada espaço de apropriação, tempo/espaço de escolhas para os acontecimentos do brincar. Para cada espaço usado pelas crianças, 'elos de sentidos' que identificaram os espaços, e desenharam os mapas e as significações que possibilitavam a construção de novos saberes ou a transformação e redimensionamento das aprendizagens a partir das vivências, experiências e experimentações.

\section{Mapas Inacabados e Considerações que Não tem Fim...}

No percurso percorrido pelos territórios da escola, no decorrer das verificações e reconhecimentos possíveis, o intuito maior era/é o de reafirmar que nesse relevo e 
paisagem desenhados na construção desta cartografia, havia assim como há, espaços outros em que a criança e suas múltiplas infâncias, se apropriam para construírem saberes, aprendizagem e novos saberes no decorrer do deleite de seus brincares.

Movimento subsidiado e reforçado pela percepção dos acontecimentos das inflexões de aprendizagem justamente no momento que surge para a criança, a oportunidade de aprender brincando, fato onde muitas possibilidades foram se concretizando e tomando formas as mais diversas.

Pois os espaços identificados nos territórios de cada escola, mesmo não sendo tais espaços considerados equipamentos específicos para o lazer, puderam ser considerados como espaços que possibilitavam o lazer para infância na escola. Espaços do brincar da criança na descoberta de sua vida e de suas infâncias. Do brincar no momento em que ela pode escolher e entender como sendo seu, para o seu lazer no tempo/espaço da escola. Neste sentido, há de se considerar, os brincares como movimento pulsante do lazer da infância e apontar o lugar que a escola pode ocupar no movimento da educação para o lazer.

E desta forma responder aos nossos questionamentos iniciais, pois nossas experimentações da realidade nos subsidiam a constatar que sim, é possível mapear espaços de lazer nos territórios da escola, e a partir destas identificações, também é possível relacionar aprendizagem com acontecimentos nos brincares e lazer das infâncias na escola.

Tempo e espaço no desenho da pesquisa, identificado como do brincar e do lazer da criança nos territórios da escola, e destes simultâneos momentos que constituem e aproximam o lazer e a educação, e que nos subsidia a pensar, perceber e compreender a ideia no entorno do 'lazer-educação’ e todas as implicações no seu entorno.

E que em nenhum momento está, esteve ou deveria estar ou se colocar como 
fixo ou regra estanque, mais em movimento pulsante, pois em outros momentos e movimentos de se pesquisar e de se perceber o fenômeno do lazer e da educação que constitui o sujeito social - criança - nos territórios da escola, pode ganhar novos rumos, novas rotas e trajetórias, novas linhas e outros contornos e desenhos na construção de novos mapas.

Nunca foi intencionalidade única determinar um desenho ou cartografia de um mapa acabado, mas apontar intencionalmente novas possibilidades de se enxergar as formas e os desenhos que se configuram no convívio dos sujeitos sociais a partir de suas práticas.

E assim, constituir mapas sempre inacabados ou em contínua construção, pois estão abertos e prontos para serem, a partir da visão de quem os configura, estuda e pesquisa modificados e contestados, desconfiando e reavaliando os acontecimentos que os constituem. E a partir daí, e por isso, receber novos contornos e constituir novos desenhos numa não linearidade em se apresentar o relevo revelado.

\section{REFERÊNCIAS}

AMADOR, F; FONSECA, T. M. G. Da instituição como método filosófico à cartografia como método de pesquisa: considerações sobre o exercício cognitivo do cartógrafo. Rio de Janeiro, Arquivos Brasileiros de Psicologia, v.61, n. 1, 2009.

CURTIS, A. O brincar em diferentes culturas e em diferentes infâncias. In: MOYLES, J. R. A excelência do brincar. Porto Alegre: Artmed, 2006.

DATTILO, John. Positive psychology and leisure education: a balanced and systematic service delivery model. Therapeutic Recreation Journal, v. 49, n. 2, p. 148-165, 2015. Disponível em: https://js.sagamorepub.com/trj/article/view/5740. Acesso em: out. 2016.

DELEUZE, G. Proust e os signos. Rio de Janeiro: Forense Universitária, 1998. 1977.

; GUATTARI, F. Kafka: por uma literatura menor. Rio de Janeiro: Imago.

; _. Mil Platôs: capitalismo e esquizofrenia. Rio de Janeiro: Ed. 34, 1996. 
DELEUZE, G.; GUATTARI, F. Mil Platôs: capitalismo e esquizofrenia. Tradução de Peter Pál Pelbart e Janice Caiafa. Rio de Janeiro: Ed. 34, 1997. v.3.

DOS ANJOS, Juliana Prochnow. Acontecimentos nas brincadeiras de rua: encontros, movimentos, experimentações. 2013. 134f. Dissertação de Mestrado em Educação. Belo Horizonte: UFMG/FaE, 2013.

EAGLETON, T. A ideia de cultura. São Paulo: Ed. UNESP, 2005.

FOUCAULT, M. As palavras e as coisas. São Paulo: Martins Fontes, 1967.

Estética: literatura e pintura, música e cinema. Organização e seleção de textos: Manoel Barros da Motta. Tradução: Inês Autran Dourado Barbosa. 2. ed. Rio de Janeiro: Forense Universitária, 2006. Coleção Ditos \& Escritos III.

Outros Espaços.1926 - 1984. In: MOTTA, Manoel Barros da (org.). Estética: literatura e pintura, música e cinema. BARBOSA, Inês Autran Dourado (Tradução). 2. ed. Rio de Janeiro: Fontense Universitária, 2009.

O corpo utópico: as heterotopias. São Paulo: n-1 Edições, 2013.

FREIRE, J. B. Jogo, Corpo e Escola. Brasília - Módulo 03 / Unidade 01/03. Brasília: CEAD, 2004.

GALLO, S. A educação menor: produção de heterotopias no espaço escolar. In: SWAIN, T. et al. Corpo, gênero e sexualidade: discutindo práticas educativas. Rio Grande: FURG, 2007.

Em torno de uma educação menor: variáveis e variações. 36a. REUNIÃO NACIONAL DA ANPED, 36, 2013. Anais... Goiânia, 2013.

GOMES, A. M. R.; FARIA, E. L. Lazer e diversidade cultural. Brasília: SESI/DN, 2005.

GOMES, C. L. Significados de recreação e lazer no Brasil: reflexões a partir da análise de experiências institucionais (1926-1964). 2003. 322f. Tese Doutorado em Educação. Belo Horizonte: UFMG/FaE, 2003.

Relações históricas: o processo de construção do lazer no mundo ocidental. In: GOMES, C. L. Lazer, trabalho e educação: relações históricas, questões contemporâneas. 2. ed. rev. e ampl. Belo Horizonte: Editora UFMG, 2008.

Ócio, recreación e interculturalidad desde el 'Sur' del mundo: desafios actuales.

Revista Polis. Santiago, Chile, n.26, ago. 2010. Disponível em: https://www.revistapolis.cl/polis\%20final/26/art09.htm. Acesso em: ago. 2018.

Lazer e formação profissional: saberes necessários para qualificar o processo formativo. In: FORTINI, J. L. M.; GOMES, C. L.; ELIZALDE, R. Desafios e perspectivas da educação para o lazer $=$ Desafíos y perspectivas de La educación para el ócio $=$ Challenges and propects of education for leisure. Belo Horizonte: Editorial SESC/Otium, 2011. 
GOMES, C. L.; PINTO, L. O lazer no Brasil: analisando práticas culturais cotidianas, acadêmicas e políticas. In: GOMES, C. L.; OSORIO, E.; PINTO, L.; ELIZALDE, R. Lazer na América latina / Tiempo Libre, Ócio y Recreacion em Latinoamerica. Belo Horizonte: Editora UFMG, 2009.

GOMES, C. L.; ELIZALDE, R. Análise teórico conceitual do lazer e da recreação na América Latina. In: GOMES, C. L.; ELIZALDE, R. Horizontes latino-americanos do lazer - Horizontes latino-americanos del ócio. Belo Horizonte: Editora UFMG, 2012.

GUATARRI, F. O inconsciente maquínico. Campinas: Papirus, 1988.

HAESBAERT, R. Des-territorialização e identidade: a rede gaucha no nordeste. Niterói: EdUFF, 1997.

KISHIMOTO, T. M. A importância do brinquedo para a educação. Revista Pedagógica. UNICHAPECÓ. Ano 4. n. 8,jan/jun. 2002. Disponível em: https://bell.unochapeco.edu.br/revistas/index.php/pedagogica/article/view/3904. Acesso em: nov. 2018.

LEAL, F. I. A importância das brincadeiras infantis para o desenvolvimento da criança: uma construção a partir do brincar. 2011. 38 f. Trabalho de conclusão de curso (licenciatura - Pedagogia) - Universidade Estadual Paulista, Instituto de Biociências de Rio Claro, 2011. Disponível em: <http://hdl.handle.net/11449/119584>. Acesso em 24 Ago. 2018.

LOPES, M. C. Ludicidade humana: contributos para a busca dos sentidos do humano. Aveiro: Universidade de Aveiro, 2004.

MARCASSA, L. Recreação. In: GOMES, C. L. (org.). Dicionário Crítico do Lazer. Belo Horizonte: Autêntica, 2004.

MARCELLINO, N. C. Pedagogia da Animação. 10. ed. Campinas: Papirus, 2012.

MASSA, M. de S. Ludicidade: da etimologia da palavra à complexidade do conceito. Rev. APRENDER: Cad. de Filosofia e Psic. da Educação. Vitória da Conquista, v. 9, n. $15,2015$.

MELLO, S. A. Infância e humanização: algumas considerações na perspectiva histórico-cultural. Perspectiva: Revista do Centro de Ciência da Educação, Florianópolis, v. 25, n.1, jan - jun. 2007.

OLIVEIRA, D. T. R. de. Brinquedos e brincadeiras populares no Programa Esporte Lazer da cidade. In: MARCELLINO, Nelson Carvalho; FERREIRA, Marcelo Pereira de Almeida (org.) Brincar, jogar, viver: programa Esporte Lazer da cidade. Brasília: Ministério do Esporte, 2007, v. I, p.127-138.

OLIVEIRA, T. R. M. de. Mapas, dança, desenhos: a cartografia como método de pesquisa em educação. In: MEYER, Dagmar E; PARAÍSO, Marlucy A. (org.) Metodologias de Pesquisas Pós-Críticas em Educação. Belo Horizonte: Mazza Edições, 2012. 
PIRES, F. F. Quem tem medo de mau-assombro? Religião e Infância no semi-árido nordestino, 2007. 235 f. Tese (Doutorado em Antropologia Social) - Museu Nacional Universidade Federal do Rio de Janeiro, Rio de Janeiro, 2007.

POCAHY, F. A. A pesquisa fora do armário: ensaio de uma heterotopia queer. Dissertação de Mestrado UFRGS: Porto Alegre, 2006.

PRONOVOST, G. Introdução a sociologia do lazer. Editora Soares: São Paulo, 2011.

RIBEIRO, C. M. Na produção das heterotopias as possibilidades de problematizar gênero e sexualidade navegando nas ambigüidades das águas. In: ANPED Sul. Univale - $\quad$ Itajaí $\quad$ SC. $2008 . \quad$ Disponível em: http://www.fastore.pt/museu/site/docs/Texto1.pdf. Acesso em: out. 2017.

Nas tendas da sexualidade e gênero: heterotopias no currículo. In: RIBEIRO, Paula R. C.; SILVA, Méri Rosane S.; GOELLNER, Silvana V. (org.) Corpo, Gênero e Sexualidade: composição e desafios para a formação docente. Rio Grande: FURG, 2009.

ROCHA, A. L. C.; ECKERT, C. Etnografia: saberes e práticas. In: PINTO, C.R.J.; GUAZZELli, C. A. B. (org.). Ciências Humanas: pesquisa e método. Porto Alegre: Editora da Universidade, 2008.

SANTOS, S. C. dos. A Importância do Lúdico no Processo de Ensino Aprendizagem. 2010. 50 f. Monografia (Especialização) - Curso de Curso de Pósgraduação à distância - Especialização Lato Sensu em Gestão Educacional, Universidade Federal de Santa Maria, Santa Maria/RS, 2010. Disponível em: https://repositorio.ufsm.br/bitstream/handle/1/393/Santos_Simone_Cardoso_dos.pdf?se quence $=1$. Acesso em: out. 2018.

SILVA, L. V. Inflexões de aprendizagem em gênero, sexualidade, raça e etnia na formação de docentes em EAD. 2013. 187 f. Dissertação de Mestrado em Educação. UFLA: Lavras MG, 2013.

; RIBEIRO, C. M. Territórios da Escola: Mapeando espaços heterotópicos de lazer que possibilitam inflexões de aprendizagem em gênero. In: SEMINÁRIO CORPO GÊNERO E SEXUALIDADE, 7, SEMINÁRIO INTERNACIONAL CORPO, GÊNERO E SEXUALIDADE, 3, LUSO BRASILEIRO EDUCAÇÃO EM SEXUALIDADE, GÊNERO, SAÚDE E SUSTENTABILIDADE. FURG, 3. Rio Grande do Norte, 2018. Disponível em: https://7seminario.furg.br/images/arquivo/147.pdf. Acesso em: dez. 2018.

SMITH, P. K. O brincar e os usos do brincar. In: MOYLES, J. et al. A excelência do brincar. Porto Alegre: Artmed, 2006.

SONTAG, S. Sobre fotografia. São Paulo: Companhia das Letras, 2004.

SPINK, M. J. P. A ética na pesquisa social: da perspectiva prescritiva à interanimação dialógica. EDIPCS. Revista semestral da Faculdade de Psicologia PUC-RS, Porto Alegre, v. 31, n. 1, pp. 7-22, jan./jul., 2000. 
SWAIN, T. N. Identidade nômade: heterotopia de mim. In: RAGO, Margareth; ORLANDI. Luiz B. L.; VEIGA-NETO, Alfredo (org). Imagens de Foucault e Deleuze: ressonâncias nietzschianas. 2. ed. Rio de Janeiro: DP\&A, 2005.

TRETTEL, U. R.; BATISTA, E. C. A importância da brincadeira no processo de ensino e aprendizagem na educação infantil. Extensivo: R. Eletr. de Extensão, Tangará da Serra - MT, v. 04, n. 1, p. 18-31, 2016. Disponível em: https://uniserratga.com.br/letter/projeto/uploads/artigos/2016/08/-1470159663.pdf. Acesso em: ago. 2018.

WINKIN, Y. A nova comunicação: da teoria ao trabalho de campo. Campinas: Papirus Editora, 1998.

\section{Endereço do Autor:}

Leandro Veloso Silva

Endereço Eletrônico: leandro.vellozo@yahoo.com.br 